\section{Scientific ruralism}

\section{David Coleman}

The Human Biology of the English Village. By G. Ainsworth Harrison. Oxford University Press: 1995. Pp. 147. £39.50.

FoR more than 15 years, from the mid1960s, Geoffrey Ainsworth Harrison's department at the University of Oxford carried out the most innovative venture in biological anthropology in the United Kingdom: to assess and describe the human biology of the population of the Otmoor villages, a rural area near Oxford. Specialists know the papers. Now we have Otmoor the book, summarizing with much charm the key findings in some 150 readable pages.

The Otmoor project, begun in 1965, was comprehensive, multidisciplinary and ambitious. Its specific aims were to establish the relationship between human genetic structure, geographical mobility and mate selection, genetic components of health and well-being, and, above all, the nature and sources of variety in a modern population.

As a study area, Otmoor has the merit of being distinct and relatively isolated and having a separate identity in the eyes of its inhabitants and neighbours. The 17 villages in 10 ecclesiastical parishes date from Anglo-Saxon times. Otmoor has none of the ex-tremes of isolation that make some human biological studies so unrepresentative.

More than 30 papers are synthesized here, with topics grouped into seven chapters on population structure, social class, mobility and ancestry, biological variation, marriage and social mobility, and the biology of everyday life and health, with a final chapter on surnames by Gabriel Lasker, who has collaborated with the study over many years.

Otmoor's fairly complete parish records were scoured to provide trends in births, deaths and marriages and then, through record linkage, to reconstruct the life events of individuals. But because the crucial facts of population size are absent before 1801, except for fragments, the vital statistics remain numerators in search of a denominator. Nonetheless, estimates indicate that villages consisted of between 40 and 86 houses in the seventeenth century, and that population began and ended the period at around 2,500.

Population movements, past and present, have churned up and flushed out the population of Otmoor. Even in the eighteenth century, more than 35 per cent of spouses married outside their parishes, increasing to 80 per cent after the $1850 \mathrm{~s}$. The distance between them increased from eight miles to thirty - a triumph of the railway and the bicycle over feet. The pattern of exchange reflects the geographical features of the area, local perception of 'otherness' and neighbourhood knowledge.

A matrix model shows the effects on ancestry of movement between parishes and between social classes. The model shows the number of generations required to generate an indistinguishable 95 per cent common ancestry between the populations, starting from an (imaginary) zero, and the pattern of relatedness that emerged. Without contributions from the 'outside world', it takes 50 generations to produce even 60 per cent common ancestry; with the outside world, just ten. A monolithic 'outside world' with such potent effects needs further subdivision.

\section{IMAGE UNAVAILABLE FOR COPYRIGHT REASONS}

to psychological factors, occupation and so on. Boredom, frustration and tiredness enhance catecholamine excretion, but the relation of these hormones to health remains unclear. Housewives and clerical workers are less healthy than average (as indeed are women in general), plagued with 'too much time on their hands'. Busy people excrete less cortisol. But, frustratingly, too much pressure may also increase output. Psychologically related illness and incapacity emerge as a particularly coherent grouping.

Lasker's innovative measure, the coefficient of relatedness through isonymy, is population genetics without genes, estimating genetic relatedness of populations through the frequency of identical surnames; here on average $75 \times 10^{-5}$. The coefficient based on rarer surnames corre-

lates well with relatedness calcu은 lated from marital migration; low levels underline the fact that local loyalties are environmental, not genetic.

In conclusion, there is no conclusion, although some of the chapters have concluding sections. The book is full of fascinating material. Because so much of the work is new, many of the lines that Harrrison and his colleagues have begun cannot easily be related to other findings. For example, few comparative data on sleep and its correlates exist for 'natural' human populations, so Harrison and his colleagues may have been victims of their own innovation. Similarly, the relevance of the findings on 'stress' and catecholamine excretion remains difficult to evaluate without definitions and consequences being made clear. And although reproduction is a preoccupation of the historical section, it hardly features in the later analysis, where its correlates could have been most minutely examined.

'Scientific ruralism' peeps out from time to time; urban areas bad, rural ones good. This is axiomatic in British society, bolstered in biology by the notion that our palaeolithic genes equip us for life in Rose Cottage, not Railway Cuttings. But as the book shows, the Otmoor population, like most other rural populations, has been urbanized by migration, media and commuting. We are all townies now.

The Otmoor study and its successful completion are a great tribute to Harrison and his collaborators. Every researcher in human biology will want to read this admirable synthesis of their results. Chasing some of the numerous hares started from the Otmoor undergrowth will keep the profession busy for some time. compared with 58 per cent of in-migrants). Only 23 per cent report an 'active social life'; 26 per cent have little or none.

An important innovation explores the relationship of sleep duration and delay (latency) - a good indicator of well-being
David Coleman is in the Department of Applied Social Studies and Social Research, University of Oxford, Barnett House, Wellington Square, Oxford OX1 2ER, UK. 